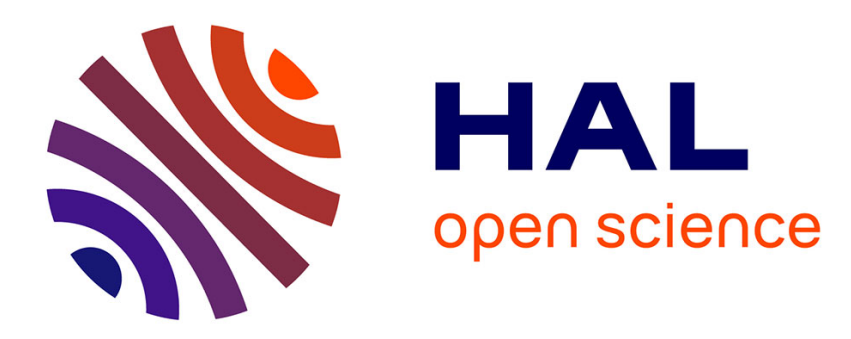

\title{
Photoelectron Diffraction: a Structural Probe for Epitaxial Thin Films
}

\author{
G. Granozzi
}

\section{To cite this version:}

G. Granozzi. Photoelectron Diffraction: a Structural Probe for Epitaxial Thin Films. Journal de Physique IV Proceedings, 1995, 05 (C5), pp.C5-861-C5-861. 10.1051/jphyscol:19955101 . jpa00253768

\section{HAL Id: jpa-00253768 https://hal.science/jpa-00253768}

Submitted on 1 Jan 1995

HAL is a multi-disciplinary open access archive for the deposit and dissemination of scientific research documents, whether they are published or not. The documents may come from teaching and research institutions in France or abroad, or from public or private research centers.
L'archive ouverte pluridisciplinaire HAL, est destinée au dépôt et à la diffusion de documents scientifiques de niveau recherche, publiés ou non, émanant des établissements d'enseignement et de recherche français ou étrangers, des laboratoires publics ou privés. 


\title{
Photoelectron Diffraction: a Structural Probe for Epitaxial Thin Films
}

\author{
G. Granozzi
}

Dipartimento di Chimica Inorganica Metallorganica ed Analitica ed Unità di Ricerca INCM, Università di Padova, Via Loredan 4, 35131 Padova, Italy

Electrons emitted from the surface region of a photon-irradiated sample undergo scattering by atoms in the vicinity of the emitting species. Subsequent interference between the direct electron wave (which propagates to the detector without undergoing any elastic scattering) and the scattered electron wave portion produces intensity modulations (up to $70 \%$ of the signal) as a function of either the direction of detection or the kinetic energy $\left(\mathrm{E}_{\mathrm{k}}\right)$ of the emitted electron. This fundamental process constitutes the physical basis of Photoelectron Diffraction (PD). The resulting modulations, properly interpreted, are rich of structural information and PD has been recently applied with success to follow the epitaxial growth of thin and ultrathin films and to study the chemisorption processes over monocrystals.

PD is a surface structural probe sensitive to short range order, with atomic and chemical state specificity. The short range order sensitivity is due to the lack of coherence between photoelectron waves emitted at different atomic sites because of the random nature of the emission process, coupled with the relatively short electron inelastic mean free paths at the energies typical for a PD experiment. On the other hand, the atomic and chemical state specificity is easily understood if one considers that PD is an implementation of the conventional X-ray Photoelectron Spectroscopy (XPS). In fact, a PD curve is obtained simply by selecting any spectral feature out of a full XPS spectrum of typically $1-1.5 \mathrm{keV}$ energy range from a single-crystalline sample, and by monitoring this particular spectral region as a function either of the emission direction or (once fixed the direction) of the $E_{k}$ of the outgoing photoelectron. PD curves can therefore be obtained for different core levels of the same element, of various elements present on the surface, and, at higher energy resolution, even of different chemical states of the same element. Coupled with the chemical specificity of the structural information, there is the capability of observing the very surface and near surface region of the sample (up to thicknesses of 20-30 $\AA$ ), due to the limited escape depths of photoelectron at the kinetic energies usually employed in PD.

In this short presentation, after a brief introduction to the principles of PD, some selected results in the field of epitaxy of semiconductor compounds and of ultrathin metallic layers will be reported in order to outline the merit of the technique. 